\title{
Development of Real-Time PCR for the Rapid Detection of Episomal Banana streak virus (BSV)
}

\author{
M. Delanoy, M. Salmon, and J. Kummert, Plant Pathology Unit, Gembloux Agricultural University, 5030 Gem- \\ bloux, Belgium; E. Frison, International Network for the Improvement of Banana and Plantain/International Plant \\ Genetic Resources Institute (INIBAP/IPGRI), 34397 Montpellier, France; and P. Lepoivre, Plant Pathology Unit, \\ Gembloux Agricultural University, Belgium
}

\begin{abstract}
Delanoy, M., Salmon, M., Kummert, J., Frison, E., and Lepoivre, P. 2003. Development of realtime PCR for the rapid detection of episomal Banana streak virus (BSV). Plant Dis. 87:33-38.

A real-time assay for the detection of episomal Banana streak virus (BSV; strain OL) in banana and plantains that carry integrated BSV sequences is described. Primers specific to the viral DNA were designed using the viral sequence integrated into the cv. Obino l'Ewai genome and the sequence of the genomic DNA of the infecting virus strain OL. They amplify a sequence of $1,336 \mathrm{bp}$ that is detected in real-time by a short fluorogenic $3^{\prime}$ minor groove binder DNA probe. This method enables reproducible and specific detection of episomal BSV from purified DNA as well as from crude extracts from infected plants. The assay is rapid, adaptable for large-scale experiments, and circumvents carryover problems.
\end{abstract}

Additional keywords: badnavirus, long amplicon, minor groove binder (MGB), Musa, $5^{\prime}$ nuclease assay

Banana streak virus (BSV) is the causal agent of viral leaf streak of banana and plantains and is the most widely distributed virus of these crops (5). The virus is a member of the plant pararetroviruses genus Badnavirus (16), with nonenveloped bacilliform particles (episomal virus) containing a 7.4-kb circular double-stranded DNA (dsDNA) genome that is replicated by reverse transcription (9). The different virus strains show a high degree of serological and genomic heterogeneity (17).

BSV infection induces yield losses and restricts the international exchange of banana germ plasm. In recent years, the virus has caused increasing concern worldwide as infection of new banana hybrids with many desirable traits frequently occurs, curtailing their exploitation. Recent reports indicate that BSV infection may arise from the activation of viral sequences that are integrated into the Musa genome $(10,20)$.

The Onne strain of BSV, now renamed BSV-OL (7), is particularly common in new hybrids developed by the international Musa breeding programs in Africa and Central and South America (3). BSV-OL sequences have been found integrated into the nuclear genome of cv. Obino l'Ewai (AAB group), which is used as a parent for

Corresponding author: P. Lepoivre

E-mail: lepoivre.p@fsagx.ac.be

Accepted for publication 16 August 2002.

Publication no. D-2002-1112-02R

(C) 2003 The American Phytopathological Society several breeding programs $(10,20)$. One of the characterized integrated sequence represents the full genome of the episomal virus BSV-OL, although the sequence is interspersed with a "scrambled" region containing inverted and noncontiguous viral and non-BSV sequences (20). This integrant recently was shown to be present in various $\mathrm{BB}$ and $\mathrm{AAB}$ cultivars and not in the AAA cultivars tested, suggesting that the integrated BSV-OL sequences are associated with the B genome of Musa (7). The sequence similarity between this integrated sequence and the genome of the virus BSV-OL argues against the activation of the integrant by excision of the scrambled region and circularization of the DNA to produce the episomal viral genome (20). Tissue culture and hybridization might be triggers for the activation of the integrant to produce BSV infection. The reasons why this activation occurs only in some plants of a given cultivar are still unknown.

This problem of virus activation suggests that traditional techniques of virus eradication, such as meristem tip culture, are not appropriate because these treatments would merely activate the integrated BSV sequences. Thus, further improvements in the production of BSV-free plants will require a better understanding of the activation process. Such information could be provided by studies on the infection frequency in the progeny of virus-free plants grown or treated under different conditions. These kinds of experiments may require the analysis of a large number of plants and, therefore, require the availability of a high throughput detection tool.
Current methods of detection of BSV include observation of symptoms, which are periodic and may be confused with those of other viruses; immunosorbent electron microscopy (ISEM), which is laborious and requires sophisticated material; enzyme-linked immunosorbent assay (ELISA), which is relatively insensitive (26); and immunocapture-polymerase chain reaction (IC-PCR), which requires pre- and postPCR steps $(4,8)$.

Real-time PCR, which increasingly is used in molecular diagnostics, eliminates the need for labor-intensive detection steps, prevents carryover contaminations and, therefore, would be particularly suitable for episomal BSV detection in large-scale experiments.

Although various types of fluorogenic probes can be used for real-time monitoring $(18,22)$, the $5^{\prime}$ nuclease assay chemistry $(1,12,15)$ is by far the most commonly used. Nevertheless, the length of the probe (25 to 40 nucleotides [nt]) which is necessary to obtain the required melting temperature (Tm) of 65 to $72^{\circ} \mathrm{C}$ can be problematic when targeting pathogens with high genomic variability. The conjugation at the $3^{\prime}$ end of the probe of a minor groove binding moiety circumvents this problem by stabilizing the probe-template duplex, increasing the melting temperature of the probe to 65 to $70^{\circ} \mathrm{C}$ even if shorter probes are used $(13,14)$.

This article describes a $5^{\prime}$ nuclease assay based on a fluorescent $3^{\prime}$ minor groove binder (MGB) probe to rapidly and reproducibly detect episomal BSV. The assay is optimized for BSV strain OL.

\section{MATERIAL AND METHODS}

Plant material. Banana cvs. FHIA 21 (AAAB, ITC 1332), Pisang Lawadin (AAB, ITC 0449), and Obino l'Ewai (AAB, ITC 0109) were provided by the International Network for the Improvement of Banana and Plantain (INIBAP) Transit Center (ITC, Leuven, Belgium). Healthy cvs. Pisang Ceylan (AAB), Williams (AAA), and Cavendish (AAA) were kindly provided by Jean-Jacques Etame (Agricultural University of Gembloux, Belgium); and cv. Butuhan (BB) was provided by Glyn Harper (John Innes Center, Norwich, UK).

Nucleic acid extraction. The extraction protocol for total nucleic acids was adapted 
from the one described by Spiegel et al. (25) for Prunus spp. Fresh material (500 $\mathrm{mg}$ ) was ground in five volumes of extraction buffer $(200 \mathrm{mM}$ Tris- $\mathrm{HCl}, \mathrm{pH} 8.5$, $1.5 \%$ sodium dodecyl sulfate, $300 \mathrm{mM}$ LiCl, $10 \mathrm{mM}$ EDTA, $1 \% \mathrm{Na}$ deoxycholate, $1 \%$ Nonidet $\mathrm{P} 40,0.5 \% \quad \beta$-mercaptoethanol). Leaf extracts were transferred to microtubes and clarified by centrifugation for $5 \mathrm{~min}$ at $7,000 \times g$ followed by a second centrifugation of the supernatant mixed with a half-volume of potassium acetate (6 $\mathrm{M}, \mathrm{pH} 6.5$ ) for $10 \mathrm{~min}$ at $12,000 \times g$. Nucleic acids contained in the supernatant were precipitated by $10 \mathrm{~min}$ of incubation at $-20^{\circ} \mathrm{C}$ with one volume of cold isopropanol followed by centrifugation for 10 $\min$ at $12,000 \times g$. The pellet was rinsed with cold ethanol $\left(70^{\circ} \mathrm{C}\right)$ and resuspended in $50 \mu \mathrm{l}$ of sterile water after air drying. Extraction purity and nucleic acid concentration were determined by measurement of the absorbance at 260 and $280 \mathrm{~nm}$ in a spectrophotometer.

Crude extract preparation for realtime PCR. Crude extracts were prepared from Musa leaves by grinding leaf tissue in 10 volumes of $137 \mathrm{mM} \mathrm{NaCl}, 8 \mathrm{mM}$ $\mathrm{Na}_{2} \mathrm{HPO}_{4}, 1.5 \mathrm{mM} \mathrm{KH} \mathrm{PO}_{4}, 2.7 \mathrm{mM} \mathrm{KCl}$, $3 \mathrm{mM} \mathrm{NaN}_{3}, 0.05 \%$ Tween 20 , and $80 \mathrm{mM}$ $\mathrm{Na}_{2} \mathrm{SO}_{3}$, pH 7.2 to 7.4 , followed by centrifugation at $7,000 \times g$ for $5 \mathrm{~min}$. The supernatant was diluted 10 times in sterile water and kept on ice prior to PCR.

Primer and probe design. Primers and probe for episomal BSV were selected from sequence alignments using PILEUP (Wisconsin Package version 10.1; Genetics Computer Group GCG, Madison, WI) on sequences available in EMBL and Genbank databases.

Comparison of the published sequences of the virus BSV-OL (AJ002234) (9) and the sequence integrated in the $\mathrm{cv}$. Obino
l'Ewai (AF106946) (20) allowed the selection of primers that only amplified sequences from episomal BSV using standard conditions. They were designed from the most conserved sequences obtained by the alignment of the sequences BSV-OL (AJ002234) (9), BSV-Mysore (AF214005), BSV-Goldfinger (AF215814), and BSVRed Dacca (AF215816) (6). The software Primer Express 5.1 (Applied Biosystems, Foster City, CA) was used for Tm calculations and primer-dimer evaluation.

The 3' MGB DNA probe was selected by following the general rules outlined by Livak et al. (15) and Kutyavin et al. (13) using the software Primer Express 5.1 for accurate $\mathrm{Tm}$ calculations. Sequences of other badnaviruses were used for the alignments: Cacao swollen shoot virus (CSSV, L14546), Sugarcane bacilliform virus (SCBV, M89923), and Rice tungro bacilliform virus (RTBV, D10774).

A

IS

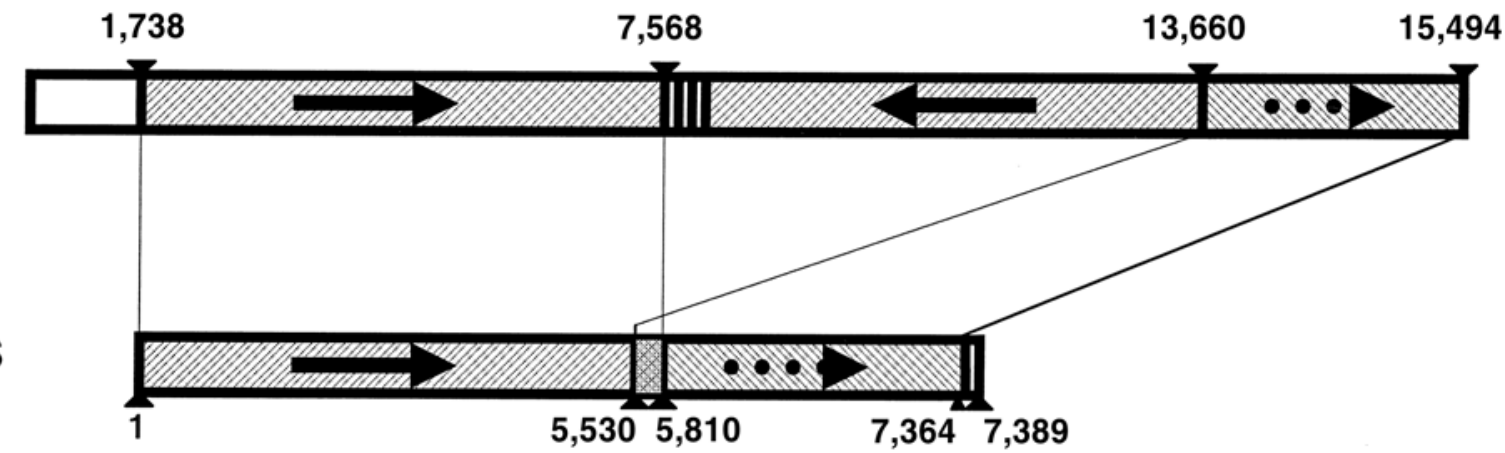

ED

B

\begin{tabular}{|c|c|c|c|c|c|}
\hline \multirow{2}{*}{$\begin{array}{c}\text { Couple of } \\
\text { primer }\end{array}$} & \multicolumn{2}{|r|}{ Forward primer } & \multicolumn{2}{|c|}{ Reverse primer } & \multirow{2}{*}{$\begin{array}{c}\text { Product } \\
\text { length (bp) }\end{array}$} \\
\hline & Position & Sequence $\left(5^{\prime}-3^{\prime}\right)$ & Position & Sequence $\left(5^{\prime}-3^{\prime}\right)$ & \\
\hline 5477F-5897R & $\begin{array}{l}5477- \\
5496\end{array}$ & $\begin{array}{l}\text { CATCAAGTAGCAATGG } \\
\text { ACCC }\end{array}$ & $\begin{array}{l}5876- \\
5897\end{array}$ & $\begin{array}{l}\text { CCAGCCATTTCCTTA } \\
\text { ATCCTIT }\end{array}$ & 420 \\
\hline 5345F-5897R & $\begin{array}{l}5345- \\
5370\end{array}$ & $\begin{array}{c}\text { TTGGTGTTTAACTATAA } \\
\text { GAGGCTGAA }\end{array}$ & $\begin{array}{l}5876- \\
5897\end{array}$ & $\begin{array}{l}\text { CCAGCCATTTCCTTA } \\
\text { ATCCTIT }\end{array}$ & 552 \\
\hline 5318F-5897R & $\begin{array}{c}5318- \\
5339\end{array}$ & $\begin{array}{c}\text { GGAAAGGAAAGAAGA } \\
\text { GGAAAGG }\end{array}$ & $\begin{array}{l}5876- \\
5897\end{array}$ & $\begin{array}{l}\text { CCAGCCATTTCCTTA } \\
\text { ATCCTIT }\end{array}$ & 579 \\
\hline 5477F-6765R & $\begin{array}{c}5477- \\
5496\end{array}$ & $\begin{array}{c}\text { CATCAAGTAGCAATGG } \\
\text { ACCC }\end{array}$ & $\begin{array}{l}6765- \\
6783\end{array}$ & $\begin{array}{l}\text { GGGTCTGGAAAGAC } \\
\text { CAAAT }\end{array}$ & 1288 \\
\hline 5477F-6105R & $\begin{array}{l}5477- \\
5496\end{array}$ & $\begin{array}{l}\text { CATCAAGTAGCAATGG } \\
\text { ACCC }\end{array}$ & $\begin{array}{l}6085- \\
6105\end{array}$ & $\begin{array}{c}\text { ATACAGCCATCCGTT } \\
\text { TCAATT }\end{array}$ & 628 \\
\hline 5477F-6119R & $\begin{array}{l}5477- \\
5496\end{array}$ & $\begin{array}{l}\text { CATCAAGTAGCAATGG } \\
\text { ACCC }\end{array}$ & $\begin{array}{l}6101- \\
6119\end{array}$ & $\begin{array}{c}\text { CTCCCCAGCCTTCCA } \\
\text { TACA }\end{array}$ & 642 \\
\hline 5477F-6681R & $\begin{array}{l}5477- \\
5496\end{array}$ & $\begin{array}{l}\text { CATCAAGTAGCAATGG } \\
\text { ACCC }\end{array}$ & $\begin{array}{l}6659- \\
6681\end{array}$ & $\begin{array}{c}\text { TTATTGCATCCACATT } \\
\text { TGAAAAC }\end{array}$ & 1204 \\
\hline 5345F-6681R & $\begin{array}{c}5345- \\
5370\end{array}$ & $\begin{array}{c}\text { TTGGTGTITAACTATAA } \\
\text { GAGGCTGAA }\end{array}$ & $\begin{array}{c}6659- \\
6681\end{array}$ & $\begin{array}{c}\text { TTATTGCATCCACATT } \\
\text { TGAAAAC }\end{array}$ & 1336 \\
\hline
\end{tabular}

Fig. 1. Selection of primers that specifically detect episomal Banana streak virus (BSV). A, Schematic representation of the genomic regions selected (F: forward primers, R: reverse primers) by comparison of the sequences of episomal BSV-OL (ES; AJ002234, 7,389 bp) and the sequence integrated in the cv. Obino l'Ewai (IS; AF106946, 15,494 bp). Regions of homologous sequence are represented by similar arrows, for which the left orientation report an inverted sequence. The vertically chopped sequence in the IS represents noncontiguous viral and non-BSV sequences. B, Sequence and position (referring to the BSV-OL sequence, AJ002234) of the selected couples of primers. 
Primers and probe were optimized for the BSV-OL strain. Primer synthesis was performed by Invitrogen (Paisley, Scotland). The MGB probe was supplied by Applied Biosystems with 6-carboxyfluorescein (FAM) as the reporter dye at the $5^{\prime}$ terminus, a nonfluorescent quencher, and the MGB moiety at the $3^{\prime}$ end.

$5^{\prime}$ nuclease assay. PCR was performed in a reaction volume of $50 \mu \mathrm{l}$ containing $0.2 \mathrm{mM}$ of each dNTP, $0.28 \mu \mathrm{M}$ of each primer, $0.1 \mu \mathrm{M}$ MGB probe, 1.4× PCR buffer, $2 \mathrm{mM}$ final $\mathrm{MgCl}_{2}$ concentration, one unit of Taq DNA polymerase (Roche Diagnostics, Belgium), and $1 \mu \mathrm{l}$ of sample. Thermal cycling conditions were $95^{\circ} \mathrm{C}$ for $1 \mathrm{~min}$ and 40 cycles of $95^{\circ} \mathrm{C}$ for $30 \mathrm{~s}, 53^{\circ} \mathrm{C}$ for $20 \mathrm{~s}$, and $60^{\circ} \mathrm{C}$ for $60 \mathrm{~s}$. To amplify from crude extracts, the number of cycles was increased to 50. The GeneAmp 5700 Sequence Detection System (Applied Biosystems) was used for thermal cycling and fluorescence recording. The threshold cycles $(\mathrm{Ct})$ were calculated by plotting normalized fluorescence $(\Delta \mathrm{Rn})$ in relation to cycle number, and correspond to the cycle number at which the fluorescence passes the threshold, from insignificant to detectable fluorescence levels (18). In all experiments, $10 \mu \mathrm{l}$ of amplified products was analyzed by gel electrophoresis for validation.

Virus purification. Purifications of BSV were done using a modified protocol from T. Ndowora (unpublished). Samples of laminae tissue (50 to $100 \mathrm{~g}$ ) powdered in liquid nitrogen were extracted with two volumes of $0.2 \mathrm{M}$ potassium phosphate, $\mathrm{pH} 6$, with $0.25 \%$ sodium sulfite (wt/vol). The extract was filtered through cheesecloth, stirred for $2 \mathrm{~h}$ with $2.5 \%$ ( $\mathrm{vol} / \mathrm{vol}$ ) Triton X-100, and centrifuged at $16,270 \times$ $g$ for $15 \mathrm{~min}\left(4^{\circ} \mathrm{C}\right)$. The supernatant was stirred for $4 \mathrm{~h}$ with $5 \%$ (wt/vol) polyethylene glycol (PEG) 8000 and then centrifuged at $23,430 \times g$ for $20 \mathrm{~min}$. The pellet was resuspended in $1 / 10$ of the original volume in $10 \mathrm{mM}$ phosphate buffer $(\mathrm{pH} 7)$ containing $0.85 \% \mathrm{NaCl}$ and conserved overnight at $4{ }^{\circ} \mathrm{C}$. After centrifugation at $12,000 \times g$ for $10 \mathrm{~min}$, the supernatant was layered over a $3.1-\mathrm{ml}$ pad of $30 \%(\mathrm{wt} / \mathrm{vol})$ sucrose in $10 \mathrm{mM}$ phosphate buffer, and centrifuged at $112,000 \times g$ for $1 \mathrm{~h}\left(4^{\circ} \mathrm{C}\right)$. The pellet was rinsed with $120 \mu \mathrm{l}$ of 10 $\mathrm{mM}$ phosphate buffer through three centrifugations at $1,200 \times g$ for $5 \mathrm{~min}$. The supernatants were pooled and concentration and purity were assessed by spectrophotometric measures at 260 and $280 \mathrm{~nm}$ ( $A_{260}$ and $A_{280}$, respectively). The viral concentration $c$ is calculated as follows: $c$ $=A_{260} / 7(\mu \mathrm{g} / \mathrm{ml})$ (B. E. L. Lockhart, personal communication).

ELISA. The triple antibody sandwich (TAS)-ELISA protocol developed by Ndowora (19) was used with BSV antisera kindly provided by Lockhart (University of Minnesota, St. Paul). Microtiter plates were incubated $\left(4 \mathrm{~h}, 37^{\circ} \mathrm{C}\right)$ with a rabbit polyclonal antiserum to BSV $(2 \mu \mathrm{g} / \mathrm{ml})$ in coating buffer $\left(35 \mathrm{mM} \mathrm{NaHCO}{ }_{3}, 14.4 \mathrm{mM}\right.$ $\mathrm{Na}_{2} \mathrm{CO}_{3}, 3 \mathrm{mM} \mathrm{NaN}, \mathrm{pH}$ 9.6). Leaf extracts were prepared by grinding in buffer (80 $\mathrm{mM} \mathrm{Na} \mathrm{Na}_{3}$ in phosphate-buffered saline [PBS]-T) at 1:4 dilution and centrifugation at $7,000 \times g$ for $5 \mathrm{~min}$. Then, supernatant was added to duplicate wells and incubated for one night at $4^{\circ} \mathrm{C}$. Chicken polyclonal antibody at 1:15000 dilution in ECI buffer $(0.2 \%$ bovine serum albumin, 2\% polyvinyl pyrrolidone-40, 3 $\mathrm{mM} \mathrm{NaN}_{3}$ in PBS-T, $\mathrm{pH}$ 7.4) was added as second antibody and incubated for $4 \mathrm{~h}$ at $37^{\circ} \mathrm{C}$. Anti-chicken immunoglobulin Galkaline phosphatase conjugate (SigmaAldrich, Bornem, Belgium) at 1:35000 dilution in ECI buffer was used as the third antibody and revealed after $2 \mathrm{~h}$ of incubation at $37^{\circ} \mathrm{C}$ with p-nitrophenyl phosphate substrate diluted 1:50 in diethanolamine at $97 \mathrm{ml} /$ liter, $1 \mathrm{mM} \mathrm{MgCl} \mathrm{m}_{2} \cdot 6 \mathrm{H}_{2} \mathrm{O}$, and $3 \mathrm{mM}$ $\mathrm{NaN}_{3}$. Absorbance readings were recorded at $405 \mathrm{~nm}\left(A_{405}\right)$ on a spectrophotometer after one night incubation at $4^{\circ} \mathrm{C}$. Absorbance values greater than twice the mean of negative controls and greater than 0.200 were considered as positive. All washes between incubation steps were done three times with PBS-T (137 mM NaCl, $8 \mathrm{mM}$ $\mathrm{Na}_{2} \mathrm{HPO}_{4} \cdot 12 \mathrm{H}_{2} \mathrm{O}, 1.5 \mathrm{mM} \mathrm{KH}_{2} \mathrm{PO}_{4}, 2.7$ $\mathrm{mM} \mathrm{KCl}, 3 \mathrm{mM} \mathrm{NaN}_{3}, 0.05 \%$ Tween 20 , $80 \mathrm{mM} \mathrm{Na} \mathrm{SO}_{3}, \mathrm{pH} 7.2$ to 7.4 ) for $3 \mathrm{~min}$. All volumes were $100 \mu$ l.

\section{RESULTS}

Primers and probe design. Although the test was developed using BSV strain OL, primers and probes always were selected in the most conserved sequences among the BSV isolates.

The comparison of the organization of the episomal BSV-OL genome with the integrated sequence in cv. Obino l'Ewai led to the selection of eight pairs of primers with forward primers located upstream of position 5,530 (BSV-OL genome) and reverse primers downstream of position 5,810 (Fig. 1). Such primers amplify a sequence from 420 to $1,336 \mathrm{nt}$ from the episomal virus. As the primers flank the "scrambled region" of the integrated sequence (minimum 6,093 bp), they will not give rise to amplification from the integrated sequence in standard conditions.

All pairs of primers were tested on plants either infected with BSV-OL (cv.
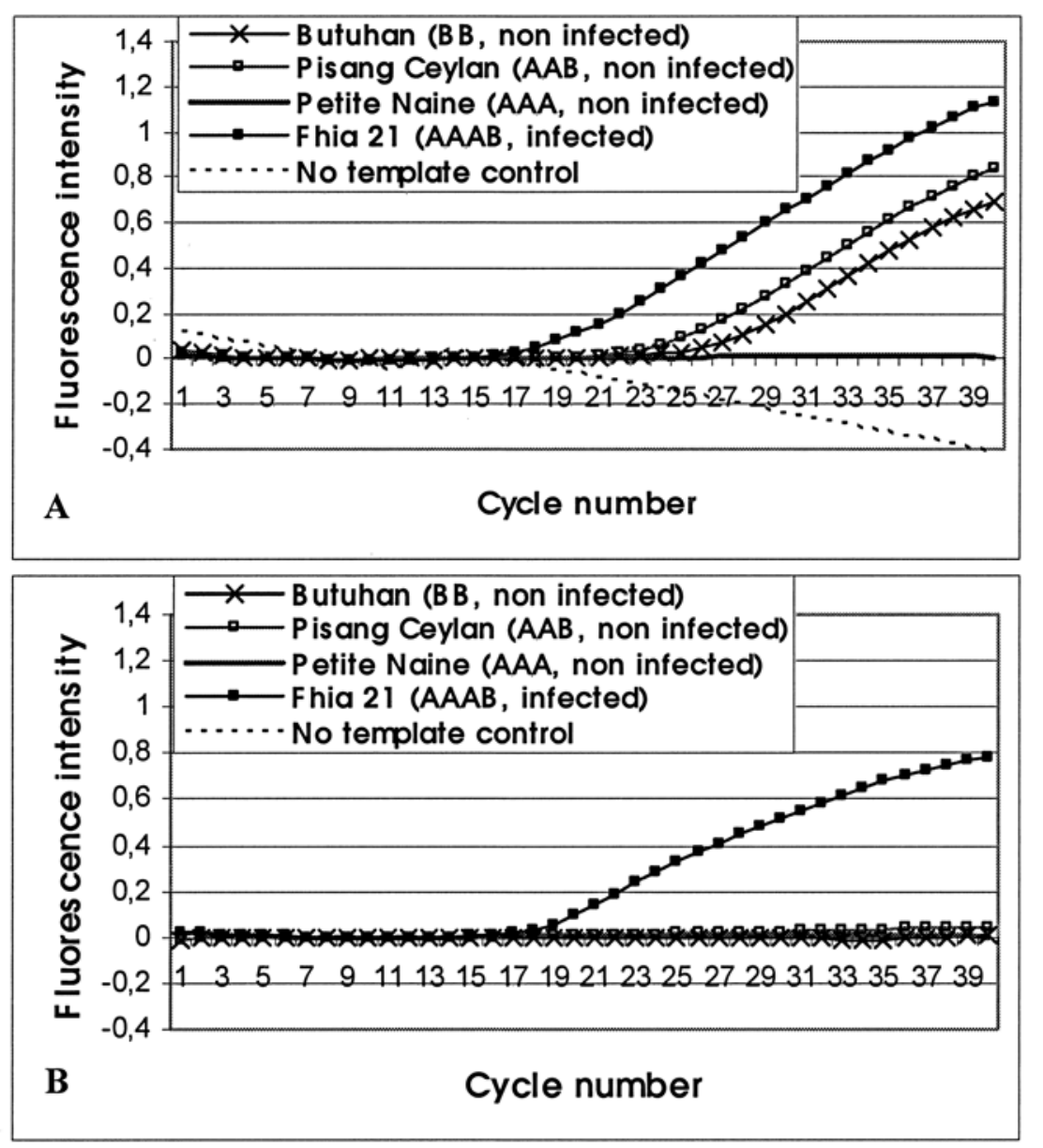

Fig. 2. Identification of primers that specifically amplify episomal viral DNA. A, Primers 5345F5897R, nonspecific; B, primers 5345F-6681R, specific. Amplifications were realized on total nucleic acids extracts from plants infected with Banana streak virus (BSV)-OL (cv. Fhia 21, AAAB group), plants noninfected and carrying (cv. Pisang Ceylan, AAB group and cv. Butuhan, BB group), or not (cv. Petite Naine, AAA group) integrated sequences related to BSV-OL. 
FHIA 21, group AAAB) or noninfected but carrying integrated sequences related to the Obino l'Ewai's integrant (cv. Pisang Ceylan, group $\mathrm{AAB}$ and cv. Butuhan, group
BB). Five primer pairs gave amplification products from both episomal and integrated BSV and were not used further (Fig. 2). These unforeseen amplifications were

A

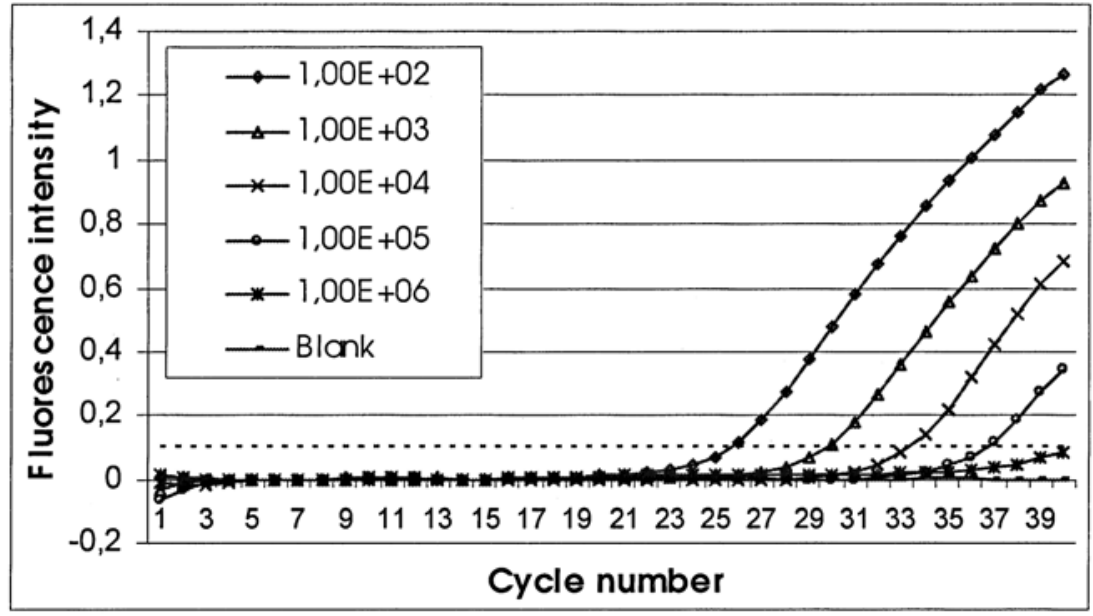

B

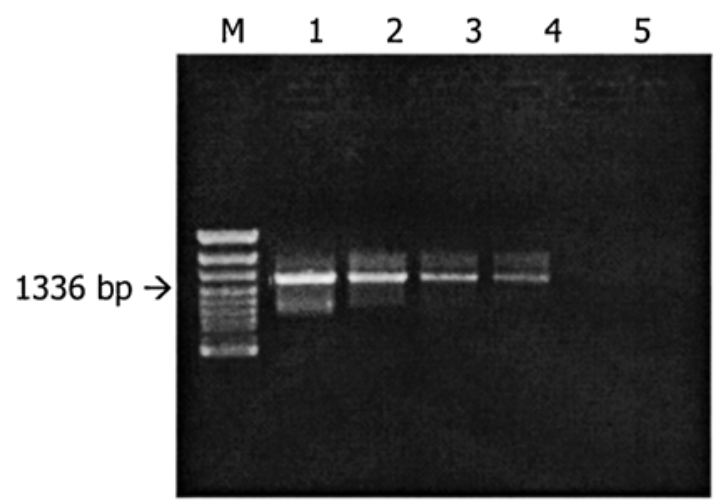

Fig. 3. Detection of episomal Banana streak virus (BSV) in total nucleic acids extracts by real-time polymerase chain reaction (PCR) using a minor groove binder DNA probe. Ten-fold dilution series (starting from dilution 1:100) of total nucleic acids extracted from BSV-infected cv. FHIA 21 (377 $\mathrm{ng} / \mu \mathrm{l})$. A, Real-time amplification plot. B, Detection of PCR products by electrophoresis in $1 \%$ agarose gel. M: 100-bp DNA ladder (GibcoBRL); lanes 1 to 5: dilutions $10^{2}, 10^{3}, 10^{4}, 10^{5}$, and $10^{6}$, respectively; lane 7: blank (sterile water). The horizontal dotted line indicates the threshold.

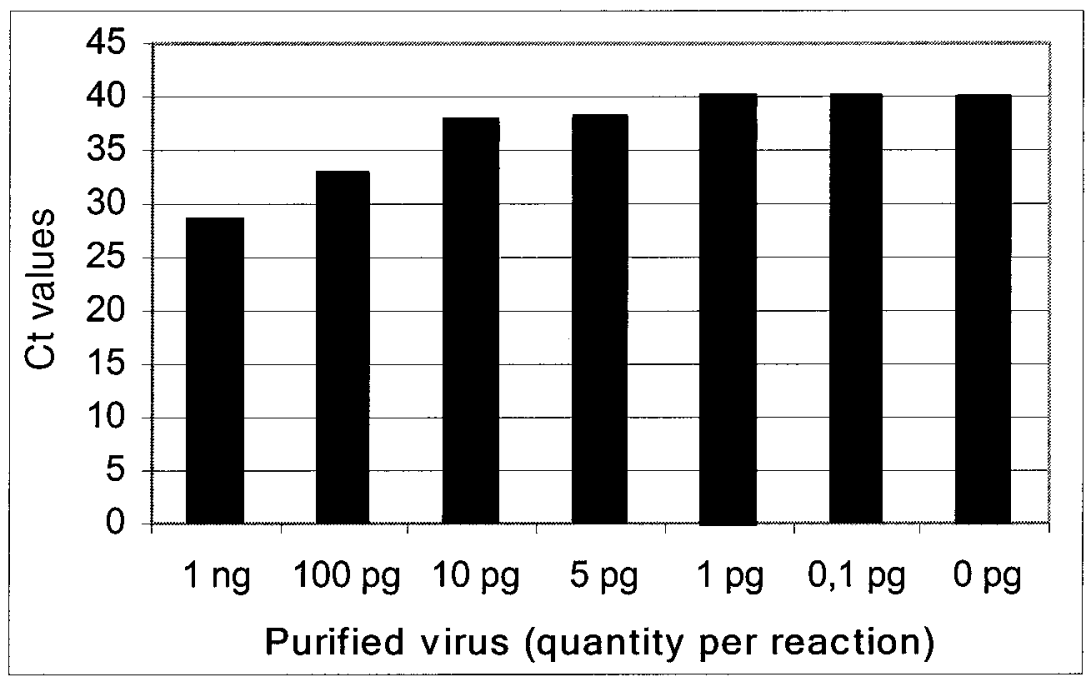

Fig. 4. Sensitivity of the real-time assay evaluated using purified virus. Virus was purified from cv. Pisang Lawadin (absorbance at $260 \mathrm{~nm} /$ absorbance at $280 \mathrm{~nm}=1.48$ ) and added to the polymerase chain reaction in the amounts indicated; $\mathrm{Ct}$ : threshold cycle.

not explained by the sequence of the Obino l'Ewai's integrant and could possibly arise from unknown rearrangements or undescribed viral integrated sequences. One pair generated a nonspecific band and two pairs produced, as expected, a unique and specific band for episomal BSV. Therefore we selected the forward primer $5345 \mathrm{~F}$ (5'TTGGTGTTTAACTATAAGAGGCTG$\mathrm{AA})$ and the reverse primer 6681R (5'TTATTGCATCCACATTTGAAAAC). They amplified a 1,336-bp sequence across the consensus sequences of the reverse transcriptase and $\mathrm{RNaseH}$ genes.

Therefore, the MGB probe (5'CAGCCTCATATTAT) was selected between primers 5345F and 6681R. It matched perfectly with both BSV-OL and BSV-Mysore strains. Probe $\mathrm{Tm}$ was estimated at $64.2^{\circ} \mathrm{C}$.

Development of real-time assay. All PCR performed from BSV-infected material produced typical fluorescent curves with $\mathrm{Ct}$ values starting from 17.51, as well as the expected band of $1,336 \mathrm{bp}$ after agarose gel electrophoresis. The real-time assay was as sensitive as the detection of the amplicon by gel electrophoresis (Fig. 3). Both techniques detected episomal BSV from $10^{5}$-fold dilutions of DNA purified from an infected plant. Using purified virus particles, the sensitivity of the realtime assay was fixed between 1 and $5 \mathrm{pg}$ (Fig. 4). The assay proved to be highly reproducible, as demonstrated by low $\mathrm{Ct}$ standard deviation values between triplicates and a high correlation coefficient ( $r=$ 0.995) of the standard curve (intra-assay variability; Fig. 5). Similar Ct values also were obtained in independent experiments, showing a good interassay reproducibility (data not shown).

Real-time assay using crude extracts. To simplify the experimental protocol and avoid a nucleic acid extraction step, the effectiveness of the real-time PCR assay was assessed on crude extracts of infected plants prepared in various extraction buffers. The lower $\mathrm{Ct}$ values were obtained using leaf extracts prepared in $137 \mathrm{mM}$ $\mathrm{NaCl}, 8 \mathrm{mM} \mathrm{Na} \mathrm{HPO}_{4} \cdot 12 \mathrm{H}_{2} \mathrm{O}, 1.5 \mathrm{mM}$ $\mathrm{KH}_{2} \mathrm{PO}_{4}, 2.7 \mathrm{mM} \mathrm{KCl}, 3 \mathrm{mM} \mathrm{NaN}$, $0.05 \%$ Tween $20,80 \mathrm{mM} \mathrm{Na} \mathrm{SO}_{3}, \mathrm{pH} 7.2$ to 7.4, and diluted 10 times. Using this dilution, no inhibitory effect of Musa crude extracts (i.e., polyphenols or polysaccharides) on PCR amplification was observed. This was confirmed by comparable $\mathrm{Ct}$ values when amplifying viral purifications diluted either in sterile water or in crude extracts of a noninfected plant (cv. Cavendish) diluted 10 and 100 times (data not shown). The use of undiluted extracts proved to have an inhibitory effect on the amplification (data not shown).

Compared with amplifications on purified nucleic acid preparations, PCR on crude extracts generated fluorescence curves with later $\mathrm{Ct}$ and lower $\Delta \mathrm{Rn}$ values (Fig. 6).

Comparison between real-time assay on crude extracts and serology (ELISA). 
To compare detection of BSV by real-time PCR and TAS-ELISA, 59 supposedly noninfected plantlets (cv. Obino l'Ewai) were analyzed in parallel by the two detection assays (data not shown). Both techniques used the same grinding buffer; therefore, a single crude extract and appropriate dilution was used for each plant. BSV was detected by real-time PCR and gel electrophoresis in eight plants, whereas none of these plants were tested positive by ELISA. The fluorescent curves of the positive plants presented $\mathrm{Ct}$ values varying from 27.95 to 47.66 .

\section{DISCUSSION}

Musa breeding programs urgently require information and understanding on BSV infection in plants that carry integrated viral sequences. So far, biological studies on BSV infection are rare because current methods of detection of episomal BSV are relatively insensitive, laborious, and not suitable to large-scale tests.

Real-time PCR has revolutionized the field of molecular diagnostics due to its rapidity, sensitivity, reproducibility, and reduced risk of carryover contamination (18). To date, applications of real-time PCR and particularly $5^{\prime}$ nuclease assay in plant virology are increasing, but the genomic variability of the virus can impair the fluorogenic process with a single TaqMan probe. Recently, Salmon et al. $(23,24)$ described a $5^{\prime}$ nuclease assay based on $3^{\prime}$ MGB probes for the real-time detection of plant viruses (Apple chlorotic spot virus and Apple stem pitting virus). The chemical modification of the probe allows the use of suitable melting temperatures with shorter probes; this property is critical to target-conserved sequences in viruses with high genomic variability.

In this article, we report the development of a real-time PCR assay to rapidly detect episomal BSV in Musa plants. The assay is optimized for the most characterized strain of BSV, BSV-OL, and constitutes a new tool to study BSV activation. The primers chosen specifically amplify episomal BSV even in the presence of viral sequences integrated in Musa spp., avoiding an immunocapture step before PCR. The MGB-fluorescent probe targets a

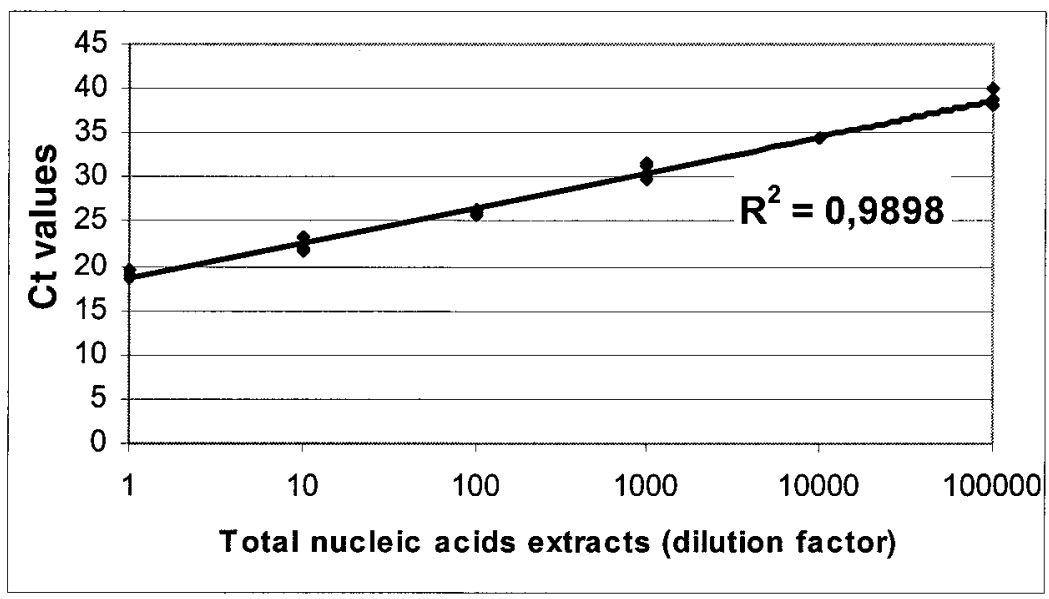

Fig. 5. Reproducibility and standard curve of threshold cycle $(\mathrm{Ct})$ values of 10-fold dilutions of total nucleic acids extracts from Banana streak virus-infected cv. FHIA 21 (377 ng/ $\mu \mathrm{l})$, tested in triplicates. unique short conserved sequence of $14 \mathrm{nt}$ and allows the fluorogenic detection of unusually long PCR products $(1,336 \mathrm{bp})$.

The assay was reproducible and as sensitive as gel electrophoresis. The virus target sequence was detected in as few as 5 pg of purified virus. The assay also provides a crude estimation of the sample viral concentration because the $\mathrm{Ct}$ values increase linearly while the amount of target decreases. The use of crude extracts as starting material allowed a further simplification of the test.

In conclusion, the real-time assay presented here detected rapidly and reproducibly episomal BSV-OL, the most characterized strain of this virus at the time of development. The test constitutes a high throughput detection method dedicated to an accurate study of the activation process of viral sequences integrated into the Musa genome. Furthermore, the quantitative property of the assay could be useful to monitor viral replication kinetics such as the progress of an infection, the response to antiviral therapy (11), and the evaluation of viral tolerance levels in new breeding programs $(2,21)$.

\section{LITERATURE CITED}

1. Bustin, S. A. 2000. Absolute quantification of mRNA using real-time reverse transcription polymerase chain reaction assays. J. Mol. Endocrinol. 25:169-193.

2. Dahal, G., Ortiz, R., Tenkouano, A., d'A Hugues, J., Thottappilly, G., Vuylsteke, D., and Lockhart, B. 2000. Relationship between natural occurrence of Banana streak badnavirus and symptom expression, relative concentration of viral antigen, and yield characteristics of some micropropagated Musa spp. Plant Pathol. 49:68-79.

3. Daniells, J. W., Geering, A. D. W., Bryde, N. J., and Thomas, J. E. 2001. The effect of $B a$ nana streak virus on the growth and yield of dessert bananas in tropical Australia. Ann. Appl. Biol. 139:51-60.

4. Delanoy, M., Jijakli, H., and Lepoivre, P. 2001. Detection of Banana streak virus (BSV) by IC-PCR-ELOSA. (Abstr.) Phytopathology 91:S22.

5. Diekmann, D. R., and Putter, C. A. J. 1996. Musa FAO/IPGRI Technical Guidelines for
Plant 1

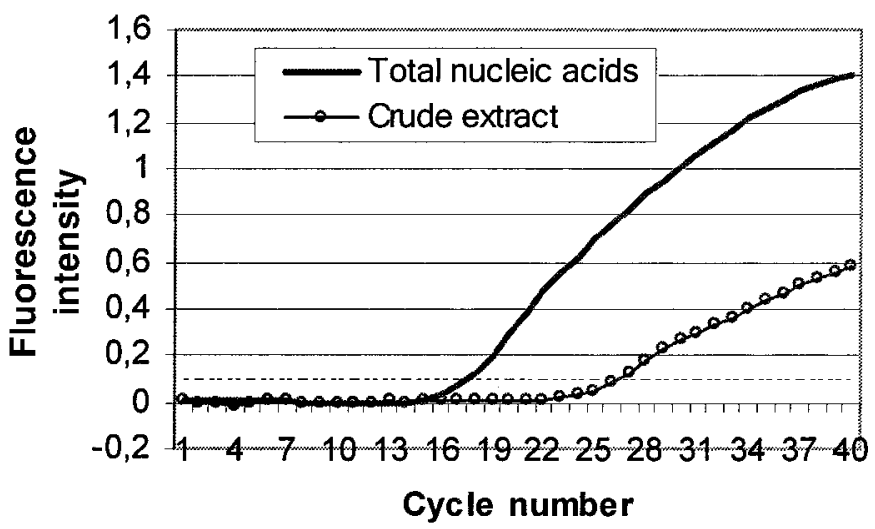

Plant 2

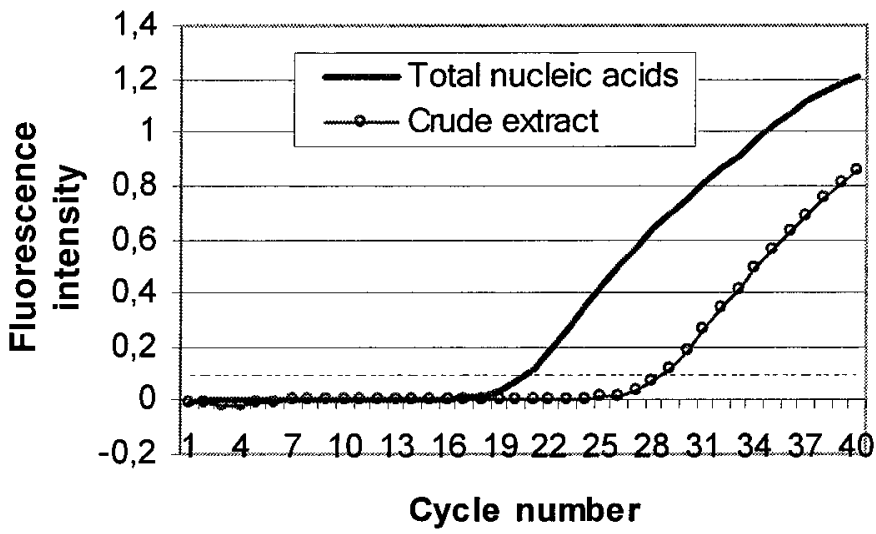

Fig. 6. Comparison of real-time polymerase chain reaction using purified nucleic acids (- - ) and crude extracts (- - -) from two Banana streak virus-infected plants (cv. FHIA 21, AAAB group). The horizontal dotted line indicates the threshold. 
the Safe Movement of Germplasm, 2nd ed. Rome.

6. Geering, A., McMichael, L., Dietzgen, R., and Thomas, J. 2000. Genetic diversity among Banana streak virus isolates from Australia. Phytopathology 90:921-927.

7. Geering, A., Olszewski, N. E., Dahal, G., Thomas, J., and Lockhart, B. 2001. Analysis of the distribution and structure of integrated Banana streak virus DNA in a range of Musa cultivars. Mol. Plant. Pathol. 2:207-213.

8. Harper, G., Dahal, G., Thottappilly, G., and Hull, R. 1999. Detection of episomal Banana streak badnavirus by IC-PCR. J. Virol. Methods 79:1-8.

9. Harper, G., and Hull, R. 1998. Cloning and sequence analysis of Banana streak virus DNA. Virus Genes 17:1-9.

10. Harper, G., Osuji, J., Heslop-Harrison, J., and Hull, R. 1999. Integration of Banana streak badnavirus into the Musa genome: molecular and cytogenetic evidence. Virology 255:207213.

11. Helliot, B., Panis, B., Poumay, Y., Swennen, R., Lepoivre, P., and Frison, E. 2002. Cryopreservation for the elimination of Cucumber mosaic and Banana streak viruses from banana (Musa spp.). Plant Cell Rep. 20:11171122.

12. Holland, P. M., Abramson, R. D., Watson, R., and Gelfand, D. H. 1991. Detection of specific polymerase chain reaction products by utilising $5^{\prime} \rightarrow 3^{\prime}$ exonuclease activity of Thermus aquaticus DNA polymerase. Proc. Natl. Acad. Sci. USA 88:7276-7280.

13. Kutyavin, I. V., Afonina, I. A., Mills, A.,
Gorn, V. V., Lukhtanov, E. A., Belousov, E. S., Singer, M. J., Walburger, D. K., Lokhov, S. G., Gall, A. A., Dempcy, R., Reed, M. W., Meyer, R. B., and Hedgpeth, J. 2000. 3'Minor groove binder-DNA probes increase sequence specificity at PCR extension temperature. Nucleic Acids Res. 28:655-661.

14. Kutyavin, I. V., Lukhtanov, E. A., Gamper, H. B., and Meyer, R. B. 1997. Oligonucleotides with conjugated dihydropyrroloindole tripeptides : base composition and backbone effects on hybridization. Nucleic Acids Res. 25:3718-3723

15. Livak, K. J., Flood, S. J. A., Marmaro, J., Giusti, W., and Deetz, K. 1995. Oligonucleotides with fluorescent dyes at opposite ends provide a quenched probe system useful for detecting PCR product and nucleic acid hybridization. PCR Methods Applications 4, 357-362.

16. Lockhart, B. 1990. Evidence for a doublestranded circular genome in a second group of plant viruses. Phytopathology 80:127-131.

17. Lockhart, B., and Olszewski, N. 1993. Serological and genomic heterogeneity of Banana streak badnavirus: implications for virus detection in Musa germplasm. Pages 105-113 in: Breeding Banana and Plantain for Resistance to Diseases and Pests. J. Ganry, ed. Proc. Int. Symp. Genet. Improv. Bananas Resist. Dis. Pests, CIRAD-FHLOR and INIBAP, Montpellier, France.

18. Mackay, I. M., Arden, K. E., and Nitsche, A. 2002. Real-time PCR in virology. Nucleic Acids Res. 30:1292-1305.

19. Ndowora, T. 1998. Development of an en- zyme immunoassay to detect serologically diverse isolates of Banana streak virus and characterization of viral sequences integrated into the Musa genome. Ph.D. thesis. University of Minnesota, St. Paul.

20. Ndowora, T., Dahal, G., LaFleur, D., Harper G., Hull, R., Olszewski, N., and Lockhart, B. 1999. Evidence that badnavirus infection in Musa can originate from integrated pararetroviral sequences. Virology 255:214-220.

21. Ortiz, R. 1996. The potential of AMMI analysis for field assessment of Musa genotypes to virus infection. Hortscience 31:829-832.

22. Salmon, M. 2002. La PCR en temps réel. Biofutur 219, Technoscope 139.

23. Salmon, M., Vendrame, M., Kummert, J., and Lepoivre, P. 2002. Detection of Apple chlorotic leaf spot virus using a 5' nuclease assay with a fluorescent $3^{\prime}$ minor groove binder-DNA probe. J. Virol. Methods 104:99106.

24. Salmon, M., Vendrame, M., Kummert, J., and Lepoivre, P. Rapid and homogenous detection of Apple stem pitting virus by RT-PCR and a fluorogenic $3^{\prime}$ minor groove binder-DNA probe. Eur. J. Plant Pathol. In press.

25. Spiegel, S., Scott, S. W., Bowman-Vance, V., Tam, Y., Galiakparov, N. N., and Rosner, A 1996. Improved detection of Prunus necrotic ringspot virus by the polymerase chain reaction. Eur. J. Plant Pathol. 102:681-685.

26. Thottappilly, G., Dahal, G., and Lockhart, B. 1998. Studies on a Nigerian isolate of Banana streak badnavirus: I. Purification and enzyme-linked immunosorbent assay. Ann. Appl. Biol. 132:253-261. 